\title{
Faktor-Faktor yang Mempengaruhi Fenomena Ketepatwaktuan Publikasi Laporan Keuangan
}

\author{
Ni Kadek Anggita Dwiantari ${ }^{1}$ \\ Fakultas Ekonomi dan Bisnis \\ Universitas Udayana, Indonesia
}

\author{
Maria Mediatrix Ratna Sari² \\ Fakultas Ekonomi dan Bisnis \\ Universitas Udayana, Indonesia
}

Surel : anggita.dwiantari@gmail.com

\section{ABSTRAK}

Ketepatwaktuan diperlukan dalam menyajikan suatu informasi yang relevan. Agar perusahaan memaparkan laporan keuangannya kepada publik tepat waktu maka harus memperhatikan faktor yang memberi pengaruh ketepatwaktuan publikasi laporan keuangan. Penelitian ini dilaksanakan agar pengaruh ukuran perusahaan, umur perusahaan serta komisaris independen akan ketepatwaktuan publikasi laporan keuangan dapat diketahui dengan subjek yakni perusahaan manufaktur sub sektor food and beverage pada Bursa Efek Indonesia (BEI) 2017-2019. Adapun jumlah sampelnya yakni 48 perusahaan yang memakai teknik purposive sampling dengan teknik analisisnya yakni analisis logistik. Berdasarkan hasil analisis diketahui bahwa ukuran perusahaan serta komisaris independen memberi pengaruh positif pada ketepatwaktuan publikasi laporan keuangan, sedangkan umur perusahaan tidak berpengaruh pada ketepatwaktuan publikasi laporan keuangan.

Kata Kunci: Ketepatwaktuan; Ukuran perusahaan; Umur perusahaan; Komisaris Independen.

\section{Factors Affecting the Phenomenon of Timeliness of Financial Report Publications}

\section{ABSTRACT}

Timeliness is needed to present relevant information. In order for a company to submit its financial reports to the public on time, it must consider the factors that affect the timeliness of the publication of financial reports. This study was done to examine the effect of company size, company age as well as independent commissioners on the timeliness of the publication of financial reports. The research was done at food and beverage sub-sector manufacturing companies listed on the Indonesia Stock Exchange at 2017-2019. The samples were 48 companies and used purposive sampling technique. The technique used was logistic analysis. The result indicated that company size and independent commissioners have a positive effect on the timeliness of the publication of financial reports. Meanwhile the age of the company had no effect on the timeliness of the publication of financial reports.

Keywords: $\quad$ Timeliness; Company Size; Company Age; Independent Commissioner.

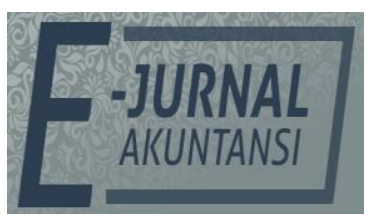

e-ISSN 2302-8556

Vol. 31 No. 2

Denpasar, Februari 2021

Hal. 374-387

DOI:

10.24843/EJA.2021.v31.i02.p09

PENGUTIPAN:

Dwiantari, N.K.A., \& Sari, M.M.R. (2021). Faktor-

Faktor yang Mempengaruhi

Fenomena Ketepatwaktuan Publikasi

Laporan Keuangan. E-Jurnal Akuntansi, 31(2), 374-387

RIWAYAT ARTIKEL: Artikel Masuk: 12 November 2020 Artikel Diterima: 8 Februari 2021

Artikel dapat diakses : https://ojs.unud.ac.id/index.php/Akuntansi/index 


\section{PENDAHULUAN}

Laporan keuangan tahunan yang terpublikasi ialah salah satu sumber informasi paling penting dikarenakan memiliki keberagaman informasi pada laporan keuangannya. Khususnya laporan keuangan memiliki peran penting bagi beberapa pihak dalam pengambilan keputusan. Informasi akuntansi berkualitas tinggi dan bermanfaat memerlukan karakteristik kualitatif, seperti relevansi informasi, komparabilitas, keandalan, dan pemahaman (Gulec, 2017). Menurut Putri \& Latrini (2018) laporan keuangan haruslah memiliki keempat karakteristik dengan tujuan informasi yang terkandung di dalamnya dapat menjadi dasar mengambil keputusan, diantaranya bisa dipahami (understandability), berkaitan (relevance), andal (reliable) serta bisa dibandingkan (comparability). Contoh karakteristik laporan keuangan yaitu relevan. Relevan yakni informasi yang ada bisa membantu para pengguna laporan keuangan ketika memutuskan hal yang berkaitan akan ekonomi. Contoh indikator pada relevan yakni ketepatwaktuan (timeliness). Informasi pada laporan keuangan dapat memberi manfaat jika dipaparkan dengan akurat serta tepat waktu.

Laporan keuangan harus dipublikasikan dengan tepat waktu kepada pengguna ketika mereka membutuhkannya untuk membuat keputusan, karena informasi kehilangan manfaatnya jika tidak tersedia saat dibutuhkan (Hung et al., 2018). Oleh karena itu publikasi tepat waktu dari laporan keuangan yang diaudit dalam laporan tahunan mempengaruhi utilitas pengambilan keputusan dan mengurangi asimetri informasi di antara para pemangku kepentingan di pasar modal (Abernathy et al., 2018). Namun, publikasi yang tepat waktu dari informasi keuangan perusahaan tergantung pada waktu yang diambil oleh auditor eksternal untuk menyelesaikan proses audit. Akibatnya, ada tekanan pada auditor eksternal untuk menerbitkan laporan audit tanpa penundaan yang tidak semestinya (Oussii et al., 2018).

Ketepatwaktuan ialah hal paling penting ketika melaporkan keuangan pada publik serta perusahaan dengan harapan untuk tak menunda pelaporan keuangan. Menurut Kamalluarifin (2016) ketepatwaktuan adalah alat penting dalam informasi keuangan karena menerima perhatian dari regulator akuntansi dan otoritas pencatatan di seluruh dunia. Ini karena kegunaan informasi terkait erat dan terkait dengan waktu pengungkapan kepada para pemangku 23 kepentingan apakah dapat memungkinkan para pemangku kepentingan untuk mengintegritaskan informasi yang diungkapkan secara efektif ke dalam pengambilan keputusan mereka. Sedangkan menurut Clatworthy et al., (2016) ketepatwaktuan adalah karakteristik kualitatif sentral dari akuntansi dan merupakan elemen mendasar dari relevansi informasi pelaporan keuangan. Ketepatwaktuan pelaporan keuangan mengacu pada periode mulai dari akhir tahun keuangan perusahaan hingga tanggal laporan tahunan yang diaudit. Hal ini diakui oleh profesi akuntansi, pengguna informasi akuntansi, dan badan pengatur dan profesional sebagai karakteristik penting dari informasi akuntansi keuangan (Attia et al., 2019). Perusahaan yang mempublikasikan laporan keuangannya dengan tepat waktu akan membuat citra perusahaan meningkat serta publik kian yakin dengan kualitas informasinya. Ketepatwaktuan juga menandakan adanya sinyal dari perusahaan dalam memperlihatkan kualitas kinerja perusahaan sekaligus kredibilitas informasi akuntansi yang tinggi terkait hal yang dilaporkan 
(Pramesti \& Suputra, 2019). Menurut Huang et al., (2017) ketepatwaktuan pengungkapan informasi keuangan telah dipertimbangkan sebagai faktor penting dalam mempromosikan fungsi ekonomi yang efisien. Studi tentang masalah ini berkisar dari hubungan antara ketepatan waktu laporan pendapatan dan harga saham di terbitkan perusahaan hingga faktor-faktor yang mempengaruhi perilaku pelaporan yang tepat waktu (Lourenco et al., 2018). Karena itu, banyak penelitian telah dilakukan tentang pengungkapan informasi keuangan yang tepat waktu dan faktor-faktor potensial yang mempengaruhi pelaporan keuangan yang tepat waktu.

Tuntutan agar patuh pada ketepatwaktuan ketika menyampaikan laporan keuangan publik di Indonesia dirumuskan pada UU No. 8 Th. 1995 mengneai Pasar Modal serta pada Keputusan Ketua BAPEPAM No. 80/PM/1996. Namun kemudian Bapepam mempererat peraturan melalui Keputusan Ketua Badan Pengawas Pasar Modal No 06/BL/2006. Peraturan ini direvisi kembali oleh OJK (Otoritas Jasa Keuangan) sehingga dikeluarkannya aturan terbaru tertanggal 29 Juli 2016 No: 29/POJK.04/2016 mengenai Laporan Tahunan Emiten yang memaparkan bahwasanya emiten diharuskan memberikan laporan keuangannya maksimal akhir bulan ke-empat (120) hari sesudah tahun buku usai. Sehubungan dengan kewajiban penyampaian laporan keuangan, OJK (Otoritas Jasa Keuangan) juga mengatur sanksi untuk perusahaan yang tak tepat waktu ketika memberikan laporan ke OJK. Perusahaan yang lambat memberikan laporan keuangan akan mendapat sanksi serta denda sesuai peraturan dari OJK.

Dirumuskannya aturan terkait adalah cerminan bahwasanya pihak yang membuat aturan (regulator) cukup serius memberi tanggapan pada kasus ketidakpatuhan dalam menyampaikan laporan keuangan. Akan tetapi, masih banyak perusahaan yang lambat memberikan laporan keuangan yang dapat dilihat dari surat pengumuman dari Bursa Efek Indonesia (BEI) yang mana tiap tahunnya masih terdapat perusahaan publik yang lambat memberikan laporan keuangan tahunannya. Pada 2018 tercatat sebanyak 15\% perusahaan manufaktur pada sub sektor food and beverage yang lambat memberikan laporan keuangannya. Pada 2019 berdasarkan surat pengumuman dari BEI mencatat bahwa perusahaan manufaktur di sub sektor food and beverage meningkat pada hal keterlambatan penyampaian laporan keuangan sebanyak 19\% dari tahun sebelumnya. Bahkan salah satu perusahaan di sub sektor food and beverage yakni PT Tiga Pilar Sejahtera Food Tbk di suspensi oleh BEI karena terlambat memberikan laporan keuangan tahun 2017 serta tak kunjung membayar denda.

Hal ini mengindikasikan regulasi bukanlah satu-satunya faktor yang memberi pengaruh pada ketepatwaktuan publikasi laporan keuangan. Banyaknya penelitian terdahulu menjelaskan bahwa faktor-faktor spesifik perusahaan memberi pengaruh pada ketepatwaktuan publikasi laporan keuangan seperti ukuran perusahaan, umur perusahaan serta komisaris independen. Ukuran perusahaan yang besar pastinya sudah didukung oleh fasilitas yang sesuai yang menyebabkan kepentingan agar selalu menyiapkan kelengkapan laporan keuangan dapat terselesaikan dengan segera. Perusahaan besar juga memiliki pengetahuan lebih terkait aturan yang berlaku, sehingga perusahaan besar cenderung taat pada aturan terkait ketepatan waktu dibanding perusahaan kecil (Rahayu \& Waluyo, 2017). 
Perusahaan didirikan untuk jangka waktu yang tidak terbatas atau panjang, tidak didirikan hanya untuk beberapa tahun saja (Kieso et al., 2018). Penelitian oleh Rahayu \& Waluyo (2017) menemukan bahwasanya umur perusahaan memberi pengaruh pada ketepatan melaporkan keuangan perusahaan. Perusahaan berumur lebih tua lebih terampil mengumpulkan, memproses, serta mendapatkan informasi yang dibutuhkan dikarenakan adanya pengalaman lebih. Hal terkait menyebabkan perusahaan bisa memaparkan laporan keungan lebih tepat waktu. Dengan kata lain, kian berumur suatu perusahaan, kian baik perusahaan terkait dalam mengendalikan hal internal dikarenakan adanya pengalaman auditor internal yang memiliki dampak kecil pada keterlambatan pelaporan.

Komisaris independen bisa mendorong manajemen agar tak berlaku curang ketika menyajikan laporan keuangan sekaligus bisa mendorong manajemen agar memberikan laporan keuangannya dengan tepat waktu. Menurut Putri \& Latrini (2018) dengan adanya komisaris independen di perusahaan, pengawasan dapat berlangsung dengan baik, hal ini dikarenakan pihak independen lebih fair dalam melakukan pengawasan. Dampak dari pengawasan yang baik tersebut adalah kinerja perusahaan yang semakin baik dan mampu menghindari keterlambatan publikasi laporan keuangannya.

Penelitian ini diadakan dengan tujuan menguji pengaruh ukuran perusahaan, umur perusahaan, serta komisaris independen akan ketepatwaktuan publikasi laporan keuangan. Penelitian ini juga bisa memberikan kontribusi positif untuk perusahaan serta manajemen sekaligus untuk peneliti selanjutnya, penelitian ini bisa dijadikan bahan rujukan acuan untuk menambah informasi terkait penelitian yang serupa.

Jensen et al., (1976) menjelaskan teori keagenan adalah merupakan hubungan kontraktual antara pihak yang mendelegasikan keputusan tertentu dengan pihak yang menerima pendelegasian tersebut. Menurut Messier et al., (2006) hubungan antara agen dan prinsipal dapat memberikan dua masalah diantaranya: (a) terjadi asimetri informasi (information asymmetry), yang mana manajemen mempunyai informasi lebih banyak terkait posisi keuangan yang sesungguhnya serta posisi operasi entitas pemilik, (b) terjadi konflik kepentingan (conflict of interest) karena perbedaan tujuan, yang mana manajemen tak bersikap sesuai akan kepentingan publik. Timbulnya asimetri informasi saat manajer lebih tahu informasi internal serta prospek perusahaan di kemudian hari nantinya dapat menjadi masalah. Kim \& Verrechia dalam Yuniarti (2018), memaparkan ketepatan pelaporan keuangan mampu meminimalisir asimetri informasi yang terjadi. Ketepatwaktuan diharapkan mampu meminimalisir kecurangan pihak agen selaku pihak dengan informasi yang lebih banyak dibanding pihak prinsipal dalam memanipulasi data (Pramesti \& Suputra, 2019).

Ketepatwaktuan berkaitan dengan teori kepatuhan. Menurut Lunenburg (2012) teori kepatuhan (compliance theory) adalah pendekatan terhadap struktur organisasi yang mengintegrasikan ideidedari model klasik dan partisipasi manajemen. Menurut Saputra, (2017) teori kepatuhan memiliki kaitan akan usaha memotivasi sikap perusahaan ketika memaparkan laporan keuangan dengan tepat waktu yakni dengan sosialisasi serta memberlakukan aturan secara ketat. Teori kepatuhan mendorong perusahaan untuk patuh terhadap peraturan dari 
OJK, yakni aturan No: 29/POJK.04/2016 terkait Laporan tahunan perusahaan publik.

Ukuran perusahaan mengindikasikan besaran informasi di dalamnya, beserta merefleksikan kesadaran pihak manajemen terkait pentingnya informasi untuk pihak eksternal serta internal (Rahayu \& Waluyo, 2017). Teori Keagenan memaparkan hubungan antar agen dengan prinsipal dapat mengakibatkan dua permasalahan keagenan yaitu adanya asimetri informasi serta konflik kepentingan. Kian besar ukuran perusahaan maka kian besar juga masalah keagenan yang terjadi. Masalah keagenan yang biasanya terjadi yakni asimetri informasi. Hal ini dapat terjadi akibat berkurangnya nilai informasi yang diterima prinsipal dapat menyebabkan terjadinya asimetri informasi karena pihak agent memiliki informasi internal perusahaan yang mendetail dibanding pihak prinsipal yang hanya memiliki informasi perusahan secara eksternal dari hasil kerja yang dilakukan manajemen. Maka dari itu perusahaan diharapkan untuk tidak menunda pelaporan keuangan kepada publik untuk menghindari terjadinya asimetri informasi. Penelitian Yuniarti (2018), Saputra (2017), Sanjaya \& Wirawati (2016), Pradipta \& Suryono (2017), Rahayu \& Waluyo (2017) menemukan bahwasanya ukuran perusahaan memberi pengaruh signifikan pada ketepatan waktu dalam menyampaikan laporan keuangan perusahaan. Lalu Mahendara \& Putra (2014) menemukan bahwasanya ukuran perusahaan tak memberi pengaruh ketepatwaktuan publikasi laporan keuangan. Penelitian Mahendara \& Putra (2014), Imaniar (2016), Indrayenti (2016), Astuti \& Erawati, (2018) juga menemukan bahwasanya ukuran perusahaan tak memberi pengaruh pada ketepatwaktuan penyampaian laporan keuangan. Berdasarkan uraian, maka dirumuskan hipotesis sebagai berikut.

$\mathrm{H}_{1}$ : Ukuran perusahaan memberi pengaruh positif terhadap ketepatwaktuan publikasi laporan keuangan.

Perusahaan lama mungkin mempunyai reputasi perusahaan lebih baik dibanding perusahaan baru. Menurut Owusu et al., (2006) perusahaan dengan umur lebih tua akan lebih terampil mendapatkan, memproses, serta menghasilkan informasi yang dibutuhkan dikarenakan perusahaan sudah mendapatkan pengalaman yang cukup. Teori kepatuhan mendorong perusahaan agar patuh pada aturan yang ada. Hal itu dapat terjadi dikarenakan bertambahnya umur perusahaan menandakan bertambahnya juga pengalaman terkait penyelesaian masalah perusahaan, sehingga secara tak langsung dapat memberikan motivasi pada perusahaan terkait pelaporan laporan keungan dengan tepat waktu. Penelitian yang dilakukan oleh Owusu et al., (2006), Pah \& Christiawan (2017), Rahayu \& Waluyo (2017), dan Nisa (2019) menyatakan bahwa umur perusahaan mempengaruhi ketepatwaktuan publikasi laporan keuangan perusahaan. Lalu penelitian oleh Indrayenti (2016), Rahayu \& Waluyo (2017), Imaniar (2016), dan Astuti \& Erawati (2018) memaparkan bahwasanya umur perusahaan tak berpengaruh pada ketepatwaktuan publikasi laporan keuangan. Berdasarkan uraian, maka dirumuskan hipotesis sebagai berikut.

$\mathrm{H}_{2}$ : Umur perusahaan memberi pengaruh positif pada ketepatwaktuan publikasi laporan keuangan.

Salah satu fungsi utama komisaris independen yakni monitoring kinerja perusahaan dengan independen, agar manajemen perusahaan dapat bekerja 
secara optimal. Komisaris independen di dalam perusahaan berfungsi untuk mengawasi perusahaan agar patuh pada aturan yang ada serta dapat memberikan laporan keuangan dengan tepat waktu. Sesuai akan teori kepatuhan komisaris independen bisa mendorong manajemen agar lebih tepat waktu pada penyampaian laporan keuangannya sehingga dapat terhindar dari keterlambatan mempublikasikan laporan keuangannya. Penelitian oleh Joened \& Damayanthi (2016), Mahendara \& Putra (2014), dan Kristiantini (2017) memaparkan bahwasanya komisaris independen memberi pengaruh positif akan ketepatwaktuan publikasi laporan keuangan. Lalu Pramesti \& Suputra (2019) menemukan bahwasanya komisaris independen tak memberi pengaruh ketepatwaktuan publikasi laporan keuangan. Berdasarkan uraian, maka dirumuskan hipotesis sebagai berikut.

$\mathrm{H}_{3}$ : Komisaris independen memberi pengaruh positif akan ketepatwaktuan publikasi laporan keuangan.

\section{METODE PENELITIAN}

Penelitian ini mengaplikasikan pendekatan kuantitatif asosiatif, yakni suatu penelitian yang memiliki tujuan mencari tahu pengaruh ukuran perusahaan, umur perusahaan serta komisaris independen akan ketepatwaktuan publikasi laporan keuangan. Penelitian ini dilaksanakan kepada perusahaan manufaktur sub sektor food and beverage di BEI selama 2017-2019. Objek penelitian ini yakni ukuran perusahaan, umur perusahaan serta komisaris independen akan ketepatwaktuan publikasi laporan keuangan perusahaan manufaktur sub sektor food and beverage selama periode 2017-2019 di BEI. Variabel independen pada penelitian ini yakni ketepatwaktuan publikasi laporan yang diukur melalui variabel dummy. Jika perusahaan tepat waktu memberikan laporan keuangannya (sebelum 120 hari sesudah akhir tahun ataupun sebelum 31 April) diberikan skor 1. Namun jika perusahaan tak tepat waktu (sesudah 120 hari sesudah akhir tahun ataupun sesudah 31 April) diberikan skor 0. Penetapan skor dilaksanakan melalui pencarian tanggal publikasi laporan keuangan di web idx dibanding Peraturan OJK. Variabel bebas yang digunakan yaitu: Ukuran perusahaan diproksikan dengan naturallog (Ln); Umur perusahaan diproksikan dengan rentangan waktu antara tahun laporan keuangan perusahaan dengan tanggal listed-nya perusahaan di pasar modal ataupun ketika proses menawar saham ke publik (IPO); Komisaris Independen diproksikan dengan proporsi komisaris independen dibandingkan jumlah dewan komisaris yang ada.

Jenis data penelitian ini yakni data kuantitatif khususnya laporan keuangan tahunan perusahaan serta data kualitatif berisikan daftar nama perusahaan selaku sampel. Sumber datanya yakni data sekunder berbentuk laporan tahunan perusahaan manufaktur sub sektor food and beverage di BEI tahun 2017-2019 dan data didapatkan melalui website BEI yakni www.idx.go.id. Penelitian ini membahas seluruh perusahaan manufaktur sub sektor food and beverage di BEI selama periode 2017-2019 selaku populasi serta menerapkan metode purposive sampling yang akhirnya mendapat jumlah sampel dengan periode pengamatan 3 tahun yakni 48 perusahaan. Kriteria-kriteria yang ditentukan yakni perusahaan manufaktur di sub sektor food and beverage yang: Memberikan laporan keuangan di BEI secara berkelanjutan selama 2017-2019; 
Laporan keuangannya berisikan laporan auditan BEI secara berkelanjutan selama 2017-2019.

Pengaruh ukuran perusahaan, umur perusahaan, serta komisaris independen pada ketepatwaktuan pelaporan keuangan bisa diketahui melalui teknik analisis logistik. Penelitian ini memakai regresi logistik dikarenakan variabel terikatnya tergolong variabel dummy. Penelitian dengan regresi logistik biner pada teknik analisis data tak membutuhkan uji normalitas akan variabel bebasnya serta mengabaikan heteroskedastisitas (Ghozali, 2018). Regresi logistik dipakai dalam uji pengaruh variabel ukuran perusahaan, umur perusahaan, serta komisaris independen terhadap ketepatwaktuan publikasi laporan keuangan perusahaan. Persamaan model regresinya sebagai berikut

$\operatorname{Ln} \frac{\mathrm{TL}}{1-\mathrm{TL}}=\alpha+\beta 1 \mathrm{X} 1+\beta 2 \mathrm{X} 2+\beta 3 \mathrm{X} 3+\varepsilon$

Keterangan:

$\operatorname{Ln} \frac{\mathrm{TL}}{1-\mathrm{TL}}=$ variabel dummy ketepatwaktuan (kategori 1 untuk perusahaan yang memberikan laporan pada akhir bulan keempat ataupun pada 30 April dan 0 untuk perusahaan yang memberikan laporan keuangannya lebih dari akhir bulan ke-empat ataupun lebih dari 30 April)

a $\quad=$ Konstanta

$\beta_{1}-\beta_{3}=$ Koefisien Regresi

$\mathrm{X}_{1} \quad=$ Ukuran Perusahaan

$\mathrm{X}_{2} \quad=$ Umur Perusahaan

$\mathrm{X}_{3} \quad=$ Komisaris Independen

$\varepsilon \quad=$ Kesalahan Residual

\section{HASIL DAN PEMBAHASAN}

Populasi penelitian ini nantinya diseleksi kembali sesuai kriteria purposive sampling yang sudah ditentukan. Proses penentuannya dipaparkan pada Tabel 1.

\section{Tabel 1. Proses Penentuan Sampel}

\begin{tabular}{clc}
\hline No. & \multicolumn{1}{c}{ Kriteria } & Jumlah \\
\hline 1. & $\begin{array}{l}\text { Perusahaan manufaktur sub sektor food and beverage yang } \\
\text { berturut-turut teregistrasi di BEI }\end{array}$ & 26 \\
$\begin{array}{l}\text { pada 2017-2019. } \\
\text { Perusahaan manufaktur sub sektor food and beverage yang tak } \\
\text { melaporkan laporan keuangan di BEI secara berturut-turut }\end{array}$ & $(10)$ \\
$\quad \begin{array}{l}\text { selama 2017-2019. } \\
\text { Perusahaan manufaktur sub sektor food and beverage yang }\end{array}$ & $(0)$ \\
$\quad \begin{array}{l}\text { laporan keuangannya tidak dilengkapi dengan laporan auditan } \\
\text { Total sampel berdasarkan kriteria }\end{array}$ & 16 \\
Tahun pengamatan & 3 \\
Total sampel penelitian selama periode pengamatan & 48
\end{tabular}

Sumber: Data Penelitian, 2020

Tabel 1, mengindikasikan jumlah populasi penelitian ini yakni 26 perusahaan sampai saat ini, namun terdapat 10 perusahaan yang tak memberi laporan keuangannya. Perusahaan manufaktur sub sektor food and beverage dengan kriteria pemilihan sampel sebanyak 16 perusahaan dengan tahun pengamatan 3 
tahun, jadi diperoleh total sampel penelitian selama periode pengamatan yakni 48 perusahaan.

Tabel 2. Hasil Analisis Statistik Deskriptif Variabel Penelitian

\begin{tabular}{llllll}
\hline & $\mathrm{N}$ & Min & Max & Mean & Std. Dev. \\
\hline Ketepatwaktuan & 48 & .00 & 1.00 & .8542 & .35667 \\
$\begin{array}{l}\text { Publikasi Laporan } \\
\text { Ukuran Perusahaan }\end{array}$ & 48 & 25.49 & 32.20 & & \\
Umur Perusahaan & 48 & 1.00 & 39.00 & 18.5202 & 1.60815 \\
Komisaris Independen & 48 & .20 & .50 & .4100 & .08310 \\
Valid N (listwise) & 48 & & & & \\
\hline
\end{tabular}

Sumber: Data Penelitian, 2020

Tabel 2, memperlihatkan Variabel Ketepatwaktuan Publikasi Laporan Keuangan (Y) mempunyai nilai minimum 0 serta nilai maksimum sebesar 1 . Hal tersebut dikarenakan peneliti menggunakan pengukuran dummy dalam mengkuantitatifkan variabel ketepatwaktuan publikasi laporan keuangan. Berdasarkan nilai minimum variabel ketepatwaktuan publikasi laporan keuangan sebesar 0 diartikan bahwa minimal perusahaan yang diteliti tidaklah tepat waktu mempublikasikan laporan keuangannya. Lalu nilai maksimum variabel ketepatwaktuan publikasi laporan keuangan sebesar 1 diartikan bahwa maksimal perusahaan yang diteliti tepat waktu ketika mempublikasikan laporan keuangannya. Nilai rata-rata variabel ketepatwaktuan publikasi laporan keuangan yakni 0.85 , dengan kata lain $85 \%$ dari perusahaan pada sampel penelitian tepat waktu ketika mempublikasikan laporan keuangannya, sedangkan sisanya sebesar $15 \%$ tak tepat waktu mempublikasikan laporan keuangannya. Adapun nilai standar deviasi variabel ketepatwaktuan publikasi laporan keuangan adalah 0.35667 yang menunjukkan adanya penyimpangan yakni 0.35667 dari rata-rata variabel ketepatwaktuan publikasi laporan keuangan.

Variabel ukuran perusahaan mempunyai nilai minimum 25,49 yakni pada perusahaan Prima Cakrawala Abadi Tbk (CEKA) pada tahun observasi 2018 serta nilai maksimum 32.20 yakni pada perusahaan PT Indofood Sukses Makmur Tbk (ICPB) pada tahun observasi 2018 serta 2019, dengan nilai rata-rata (mean) 28,5202 beserta nilai standar deviasi yakni 1,60815 yang bermakna adanya penyimpangan 1,60815 dari rata-rata variabel ukuran perusahaan.

Variabel umur perusahaan mempunyai nilai minimum 1,00 yakni pada PT Campina Ice Cream Industi Tbk (CAMP), PT Sariguna Primarta Tbk (CLEO), PT Buyung Poetra Sembada Tbk (HOKI) dan PT Prima Cakrawala Abadi Tbk (PCAR) serta nilai maksimum 39,00 yakni pada perusahaan PT Multi Bintang Indonesia Tbk (MLBI), dengan nilai rata-rata (mean) 18,6250 serta nilai standar deviasi sebesar 12,15962 yang menunjukkan adanya penyimpangan 12,15962 dari ratarata variabel umur perusahaan.

Variabel komisaris independen mempunyai nilai minimum 0,20 yakni pada perusahaan PT Tiga Pilar Sejahtera Food Tbk (AISA) serta nilai maksimum 0,50 yakni pada salah satu perusahaan PT Tri Bayan Tirta Tbk (ALTO) dengan nilai rata-rata (mean) sebesar 0,4100 serta nilai standar deviasinya 0,8310 yang bermakna adanya penyimpangan 0,8310 dari rata-rata variabel komisaris independen. 
Tabel 3. Hasil Uji Kelayakan Model Regresi

\begin{tabular}{clll}
\hline Step & Nilai Chi-square & Df & Signifikansi \\
\hline 1 & 1,741 & 8 & 0,988 \\
\hline
\end{tabular}

Sumber: Data Penelitian, 2020

Tabel 3, menunjukkan angka Chi-Square yakni 1,741 dengan angka probabilitas signifikansinya yakni $0,988>0,05$. Hal terkait memperlihatkan bahwasanya $\mathrm{H}_{0}$ diterima yang bermakna model regresi layak dipakai dikarenakan tak terdapat perbandingan nyata atau signifikan antara prediksi klasifikasi dengan klasifikasi yang diobservasi (model dengan nilai observasinya).

Tabel 4. Hasil Uji Keseluruhan Model (Overall Model Fit)

\begin{tabular}{ll}
\hline Iteration & -2 Log likelihood \\
\hline Step 0 & 53,984 \\
Step 1 & 45,125 \\
\hline
\end{tabular}

Sumber: Data Penelitian, 2020

Tabel 4, memperlihatkan nilai -2 Log likelihood saat step 0 sebesar 53.984 lalu pada nilai -2 Log likelihood saat step 1 mengalami penurunan sebesar 45.125. Berarti -2 Log likelihood saat step $0>-2$ Log likelihood saat step 1, jadi model regresi disebut layak ataupun baik dikarenakan adanya penurunan nilai dari step 0 hingga step 1.

Tabel 5. Hasil Uji Koefisien Determinasi

\begin{tabular}{llll}
\hline Step & -2 Log likelihood & Cox E Snell R Square & Nagelkerke $R$ Square \\
\hline 1 & $41,537^{a}$ & 0,228 & 0,338 \\
\hline
\end{tabular}

Sumber: Data Penelitian, 2020

Tabel 5, menyajikan nilai Nagelkerke R Square yakni 0,338 yang bermakna variabilitas variabel dependen bisa dijelaskan melalui variabilitas variabel independen yakni ukuran perusahaan, umur perusahaan, beserta komisaris independen yakni $33,8 \%$, lalu sisanya $66,2 \%$ variabilitas pada variabel dependen dipaparkan oleh faktor-faktor lainnya di luar variabel independen penelitian.

Tabel 6. Variables in the Equation

\begin{tabular}{|c|c|c|c|c|c|c|c|}
\hline & & B & S.E. & Wald & Df & Sig. & $\operatorname{Exp}(\beta)$ \\
\hline \multirow[t]{4}{*}{ Step $1^{a}$} & $\begin{array}{l}\text { Ukuran } \\
\text { Perushan }\left(X_{1}\right)\end{array}$ & 0,929 & 0,426 & 4,761 & 1 & 0,029 & 2,531 \\
\hline & $\begin{array}{l}\text { Umur } \\
\text { Perusahaan }\left(\mathrm{X}_{2}\right)\end{array}$ & 0,044 & 0,035 & 1,541 & 1 & 0,214 & 0,957 \\
\hline & $\begin{array}{l}\text { Komisaris } \\
\text { Independen }\left(X_{3}\right)\end{array}$ & 0,102 & 0,049 & 4,404 & 1 & 0,036 & 1,108 \\
\hline & Constant & 28,290 & 12,413 & 5,194 & 1 & 0,023 & 0,000 \\
\hline
\end{tabular}

Sumber: Data Penelitian, 2020

Nilai konstanta bertanda positif sebesar 28,290 maka dapat diartikan apabila ukuran perusahaan, umur perusahaan, beserta komisaris independen bernilai konstan, nilai ketepatwaktuan publikasi laporan keuangan tahunannya sebesar 28,290 satuan.

Nilai koefisien variabel ukuran perusahaan bertanda positif yakni 0,929 maka artinya bila nilai ukuran perusahaan meningkat satu satuan, nilai ketepatwaktuan publikasi laporan keuangannya cenderung meningkat 0,929 satuan dengan asumsi faktor lain tetap. 
Nilai koefisien variabel umur perusahaan yakni 0,044 maka artinya apabila nilai umur perusahaan meningkat satu satuan, nilai ketepatwaktuan publikasi laporan keuangannya cenderung meningkat 0,044 satuan dengan asumsi faktor lain tetap.

Nilai koefisien variabel komisaris independen yakni 0,102 maka artinya apabila nilai komisaris independen meningkat satu satuan, nilai ketepatwaktuan publikasi laporan keuangannya cenderung meningkat 0,102 satuan dengan asumsi faktor lain tetap.

Uji hipotesis penelitian ini dilaksanakan melalui perbandingan tingkat signifikansi (sig) dan tingkat kesalahan $(\alpha)=5 \%$ serta nilai koefisien $\beta$ agar mengetahui pengaruh positif ataupun negatif. Jika angka signifikansinya 0,05 (sig $\leq \alpha)$, variabel bebasnya memberi pengaruh signifikan akan variabel terikat, serta bila angka signifikansinya $>0,05$ ( $\operatorname{sig} \geq a$ ), variabel bebasnya tak memberi pengaruh variabel terikat. Pada Tabel 6, diperoleh nilai signifikansi uji t dari variabel ukuran perusahaan adalah $0.029(<0.05)$ dengan nilai koefisien regresinya adalah 0.929. Angka tersebut mengindikasikan ukuran perusahaan memberi pengaruh positif pada ketepatwaktuan publikasi laporan keuangan, jadi kesimpulannya adalah hipotesis pertama diterima. Hal tersebut selaras dengan teori keagenan yang memaparkan bahwa hubungan agen dan prinsipal mampu mengakibatkan permasalahan keagenan yaitu terjadinya asimetri informasi serta konflik kepentingan. Kian besar ukuran perusahaan, kian besar juga masalah keagenan yang terjadi. Masalah keagenan yang biasanya terjadi yakni asimetri informasi. Hal ini dapat terjadi akibat berkurangnya nilai informasi yang diterima prinsipal dapat menyebabkan terjadinya asimetri informasi dikarenakan pihak agent memiliki informasi internal perusahaan secara mendetail dibanding pihak prinsipal yang hanya tahu informasi perusahan secara eksternal dari hasil kerja yang dilakukan manajemen. Untuk menghindari terjadinya asimetri informasi, perusahaan besar lebih tepat waktu memberikan laporan keuangan, dikarenakan canggih dan kuatnya staf akuntansi, sistem informasi, sekaligus sistem pengendalian internnya (Sanjaya \& Wirawati, 2016). Selain itu perusahaan besar memiliki tekanan agar segera memberikan laporan keuangannya karena perusahaan besar diawasi banyaknya pihak yang membuat tingkatan kepatuhanperusahaan besar tak sama akan perusahaan kecil. Jika dalam menyampaikan laporan keuangannya terlambat, dapat megakibatkan asimetri informasi serta adanya spekulasi pada perdagangan saham (Saputra, 2017). Hasil penelitian ini selaras dengan penelitian Yuniarti (2018), Saputra (2017), Sanjaya \& Wirawati (2016), Pradipta \& Suryono (2017), Rahayu \& Waluyo (2017) yang menemukan bahwasanya ukuran perusahaan memberi pengaruh pada ketepatwaktuan publikasi laporan keuangan.

Berdasarkan Tabel 6, diperoleh nilai signifikansi uji $t$ variabel umur perusahaan adalah $0.214(>0.05)$ dengan nilai koefisien regresi adalah 0.044. Angka tersebut memperlihatkan bahwasanya umur perusahaan tak memberi pengaruh terhadap ketepatwaktuan publikasi laporan keuangan, jadi kesimpulannya adalah hipotesis kedua ditolak. Hasil penelitian mengindikasikan tua atau muda umur perusahaan tidaklah memberi pengaruh pada ketepatwaktuan publikasi laporan keuangan perusahaan tersebut. Hal tersebut tidaklah sesuai akan teori kepatuhan yang menjelaskan kian tua umur perusahaan, kian tepat waktu perusahaan 
tersebut memberikan laporan keuangannya. Karena sesuai akan peraturan OJK No. 29/PJOK.04/ 2016 yang berisi bahwasanya emiten diwajibkan memberi laporan keuangan tahunannya maksimal akhir bulan keempat setalah tahun buku berakhir, jadi tua ataupun mudanya umur sebuah perusahaan haruslah tetap memberi laporan keuangan dengan tepat waktu dikarenakan aturan tersebut diberlakukan untuk semua perusahaan di BEI. Joened \& Damayanthi (2016) memaparkan bahwasanya perusahaan baru cendrung menerbitkan laporan keuangannya dengan cepat agar memberikan bukti bahwasanya kinerja mereka untuk menarik investor dan bersaing dengan perusahaan lama. Hasil penelitian ini selaras dengan Indrayenti (2016), Rahayu \& Waluyo (2017), Imaniar (2016), dan Astuti \& Erawati (2018) yang menemukan bahwasanya umur perusahaan tidaklah memberi pengaruh pada ketepatwaktuan publikasi laporan keuangan.

Berdasarkan Tabel 6, diperoleh nilai signifikansi uji $\mathrm{t}$ dari komisaris independen adalah $0.036(<0.05)$ dengan nilai koefisien regresi adalah 0.102 . Angka tersebut mengindikasikan komisaris independen memberi pengaruh positif pada ketepatwaktuan publikasi laporan keuangan, jadi kesimpulannya adalah hipotesis ketiga diterima. Hasil penelitian ini menjelaskan adanya komisaris independent membantu manajemen perusahaan agar bekerja dengan optimal. Hal tersebut selaras akan teori kepatuhan yang memaparkan bahwasanya komisaris independen mampu mendorong manajemen agar lebih tepat waktu memaparkan laporan keuangannya berdasarkan peraturan OJK No 29/PJOK.04/ 2016 sehingga dapat menghindari keterlambatan sekaligus terhindar dari sanksi yang telah ditetapkan apabila perusahaan terlambat memberikan laporan keuangannya. Komisaris independen bertugas untuk mengawasi perusahaan serta memastikan perusahaan agar memberi informasi yang lebih baik sehingga dapat melindungi stakeholders dari informasi yang tidak benar sekaligus menghindarkan dari fraud serta insider informasi yang hanya memberi keuntungan pada beberapa pihak. Sehingga komisaris independen di dalam perusahaan haruslah benar-benar independen serta terlepas dari campur tangan pihak lain untuk memastikan laporan keuangan tahunan sudah valid serta bisa dipertanggungjawabkan. Hasil penelitian ini selaras dengan Joened \& Damayanthi (2016), Mahendara \& Putra (2014), dan Kristiantini (2017) yang menemukan bahwasanya komisaris independen memberi pengaruh ketepatwaktuan publikasi laporan keuangannya.

\section{SIMPULAN}

Hasil analisis data memperlihatkan ukuran perusahaan serta komisaris independen memberi pengaruh positif akan ketepatwaktuan publikasi laporan keuangan. Lalu umur perusahaan tak memberi pengaruh akan ketepatwaktuan publikasi laporan keuangan. Peneliti selanjutnya sebaiknya dapat melakukan penelitian di lokasi yang berbeda atau memperluas lokasi penelitian pada sub sektor lain contohnya sektor manufaktur ataupun meneliti semua perusahaan (tak hanya satu sektor tertentu) di BEI sehingga dapat memperluas penelitian sebelumnya.

Saran terkait penelitian ini yaitu penelitian seterusnya dapat menggunakan variabel independen lain yang memberi pengaruh pada ketepatwaktuan publikasi laporan keuangan serta jangka waktu yang digunakan 
lebih diperpanjang agar hasil penelitiannya. Untuk pihak manajemen perusahaan agar lebih memberi perhatian pada ketepatwaktuan publikasi laporan keuangan agar sesuai akan ketentuan yang sudah ditentukan Otoritas Jasa Keuangan (OJK).

\section{REFERENSI}

Abernathy, J. L., Kubick, T. R., \& Masli, A. (2018). Evidence on the relation between managerial ability and financial reporting timeliness. International Journal of Auditing, 22(2), 185-196. https://doi.org/10.1111/ijau.12112

Astuti, W., \& Erawati, T. (2018). Pengaruh Profitabilitas , Umur Perusahaan Dan Penyampaian Laporan Keuangan Perusahaan (Studi pada perusahaan manufaktur yang Terdaftar di Bursa Efek Indonesia Tahun 2012-2016 ). Jurnal Kajian Bisnis, 26(2), 144-157.

Ben Rejeb Attia, M., Lassoued, N., \& Sassi, H. (2019). Financial reporting timeliness and the value relevance of earnings: Evidence from banks in the MENA countries. International Trade Journal, 33(3), 277-301. https://doi.org/10.1080/08853908.2018.1459212

Clatworthy, M. A., \& Peel, M. J. (2016). The timeliness of UK private company financial reporting: Regulatory and economic influences. British Accounting Review, 48(3), 297-315. https://doi.org/10.1016/j.bar.2016.05.001

Güleç, Ö. F. (2017). Timeliness of corporate reporting in developing economies: Evidence from Turkey. Journal of Accounting and Management Information Systems, 16(3), 219-239. https://doi.org/10.24818/jamis.2017.03001

Ha, H. T. V., Hung, D. N., \& Phuong, N. T. T. (2018). The study of factors affecting the timeliness of financial reports: The experiments on listed companies in Vietnam. Asian Economic and Financial Review, 8(2), 294-307. https://doi.org/10.18488/journal.aefr.2018.82.294.307

Huang, H. W., Dao, M., \& Sun, W. C. (2017). The Timeliness of Financial Reporting and Fair Values: Evidence from U.S. Banks. Review of Pacific Basin Financial Markets and Policies, 20(1), 1-30. https://doi.org/10.1142/S0219091517500060

Ie, I. C. (2016). Analisis Faktor-Faktor Yang Mempengaruhi Ketepatan Waktu Penyampaian Laporan Keuangan Pada Perusahaan Manufaktur Yang Terdaftar Di Bursa Efek Indonesia. Universitas Bandar Lampung IOSR Journal of Economics and Finance, 3(1), 56. https://doi.org/https://doi.org/10.3929/ethz-b-000238666

Imam Ghozali. (2018). Aplikasi Analisis Multivari-ate dengan Program SPSS. Semarang: Semarang: Badan Penerbit Universitas Diponegoro.

Imaniar, F. Q. (2016). Faktor-Faktor yang Mempengaruhi Ketepatan Waktu Pelaporan Keuangan Perusahaan. Ilmu Dan Riset Akuntansi, 5(2460-0585).

Jensen, M. C.,\& Meckling, W. H. (1976). The theory of the firm, managerial ownership, agency cost and ownership structure. Journal of Financial Economics, 3, 305-361.

Joened, J., \& Damayanthi, I. (2016). Pengaruh Karakteristik Dewan Komisaris, Opini Auditor, Profitabilitas, Dan Reputasi Auditor Pada Timeliness of Financial Reporting. E-Jurnal Akuntansi, 14(1), 423-450.

Kamalluarifin, W. F. S. W. (2016). The Influence of Corporate Governance and Firm Characteristics on the Timeliness of Corporate Internet Reporting By Top 95 
Companies in Malaysia. Procedia Economics and Finance, 35(16), 156-165. https://doi.org/10.1016/s2212-5671(16)00020-4

Kieso, D. E., Weygand, \& Warfield. (2018). Intermediate Accounting IFRS. Jakarta: Jakarta: Erlangga.

Komang Wahyu Surya Saputra, I. W. R. (2017). Pengaruh Profitabilitas Dan Ukuran Perusahaan Terhadap Ketepatan Waktu Pelaporan Keuangan Dengan Opini Audit Sebagai Pemoderasi. E-Jurnal Akuntansi, 20, 1592-1620. https:// doi.org/10.24843/EJA.2017.v20.i02.p26

Kristiantini, M, D, Sujana, I. K. (2017). Pengaruh Opini Audit, Audit Tenure, Komisaris Independen, Dan Kepemilikan Manajerial Pada Ketepatwaktuan Publikasi Laporan Keuangan. E-Jurnal Akuntansi, 20.1, 729-757.

Lourenço, I. C., Branco, M. C., \& Curto, J. D. (2018). Timely reporting and family ownership: the Portuguese case. Meditari Accountancy Research, 26(1), 170192. https:/ / doi.org/10.1108/MEDAR-05-2016-0058

Lunenburg, F. C. (2012). Compliance Theory and Organizational Effectiveness. In International Journal of Scholarly Academic Intellectual Diversity (Vol. 14).

Mahendara, I. B. K. Y., \& Putra, I. N. W. A. (2014). Pengaruh Komisaris Independen, Kepemilikan Institusional, Profitabilitas, Likuiditas dan Ukuran Perusahaan Terhadap Ketepatwaktuan. E-Jurnal Akuntansi Universitas Udayana, 9(1), 180-199.

Messier, W. F., Glover, S. M., \& Prawitt, D. F. (2006). Auditing \& Assurance Service: A Systematic Approach. In United States of America, New York: McGraw-Hill Education (Edisi Keem). Jakarta: Salemba Empat.

Nisa, R. A. S. (2019). Pengaruh Profitabilitas, Ukuran Perusahaan, Likuiditas dan Umur Perusahaan Terhadap Ketetapan Waktu Pelaporan Keuangan Perusahaan Manufaktur. Jurnal Akuntansi STIE Perbanas.

Oussii, A. A., \& Boulila Taktak, N. (2018). Audit committee effectiveness and financial reporting timeliness: The case of Tunisian listed companies. African Journal of Economic and Management Studies, 9(1), 34-55. https:// doi.org/10.1108/ AJEMS-11-2016-0163

Owusu-Ansah, S., \& Leventis, S. (2006). Timeliness of corporate annual financial reporting in Greece. European Accounting Review, 15(2), 273-287. https://doi.org/10.1080/09638180500252078

Pah, H. L., \& Christiawan, Y. J. (2017). Pengaruh Kepemilikan Keluarga Terhadap Profitabilitas Dengan Firm Age, Firm Size, Dan Leverage Sebagai Variabel Kontrol. Busuness Accounting Review, 5(2), 409-420.

Pradipta, D. N., \& Suryono, B. (2017). Analisis Faktor-Faktor Yang Mempengaruhi Ketepatan Waktu. Jurnal Ilmu Dan Riset Akuntansi, 6, 1-17.

Pramesti, N. M. M. D., \& Suputra, D. G. D. (2019). Pengaruh Financial Distress, Komisaris Independen, Kepemilikan Institusional, Audit Tenure, dan Reputasi Kantor Akuntan Publik Pada Ketepatwaktuan Publikasi Laporan Keuangan. E-Jurnal Akuntansi, 881. https://doi.org/10.24843/ eja.2019.v26.i02.p02

Putri, N. P. W. A., \& Latrini, Y. (2018). Dewan Komisaris Independen sebagai Pemoderasi Pengaruh Financial Distress pada Kecepatan Publikasi Laporan Keuangan. E-Jurnal Akuntansi, 22, 2204. https://doi.org/10.24843/eja.2018.v22.i03.p21 
Rahayu, R. D. T., \& Waluyo, I. (2017). Pengaruh Ukuran Perusahaan, Umur Perusahaan, Opini Auditor, dan Kepemilikan Publik Terhadap Ketepatan Waktu Penyampaian Laporan Keuangan (Studi Empiris pada Perusahaan Manufaktur yang Terdaftar di BEI Periode 2011-2015). Jurnal Pendidikan Akuntansi, 6(1), 1-23.

Sanjaya, I. M. D. M., \& Wirawati, N. G. P. (2016). Analisis Faktor-Faktor Yang Mempengaruhi Ketepatan Waktu Pelaporan Keuangan Pada Perusahaan Manufaktur Yang Terdaftar Di Bei I. E-Jurnal Akuntansi Universitas Udayana, 15, 17-26.

Yuniarti, R. (2018). Rina Yuniarti Pengaruh Likuiditas, Ukuran Perusahaan Dan Reputasi KAP. Baabu Al-Ilmi, 1, 127-145. 